\title{
Leszek Kwieciński
}

\section{“NEW PUBLIC POLICY” AS AN EXAMPLE OF PRO-INNOVATION POLICY - THE NEO-INSTITUTIONAL PERSPECTIVE}

DOI: $10.1515 /$ ppsr-2015-0014

\begin{abstract}
This article presents the main elements of the creation of the pro-innovation policy as a new public policy. For understanding this kind of policy we should analyse the structural and functional aspects this public policy. The main concept of structural description pro-innovation policy is a National Innovation System. NIS is being analysed as a sub-functional part of the political system as a whole. This sub-functional political system should also have social and institutional connections. Furthermore, pro-innovation activity is connected with the market, state, and social aspects. The pro-innovation policy and system must be based on social endogenous resources, needs, and possibilities. These are the basic factors for legitimisation and participation, which are crucial elements for the effective implementation of the pro-innovation policy.
\end{abstract}

Keywords: pro-innovation policy, national innovation system, public policy

\section{Introduction - context of research}

The 1990s can be considered to be an informal opening of the discussion on social, economic, and political changes which should be connected with the processes of modernisation, competitiveness, society, and knowledge-based economy, and consequently innovativeness, innovation, and pro-innovation policy. All kinds of structural and normative issues connected with the innovative processes are presented as priorities both in the sphere of discourse (declarative), and in the sphere of strategic operations of the entities on a macro scale (international organisations, countries, transnational corporations), micro scale (regions, local communities, social and civic stakeholders, individuals) as well as mezzo scale (regarding virtually all kinds of economic operations). On the other hand, in the sphere in question, the innovative processes include such soft factors as activity and behaviour of individuals, transformations of social structures, social capital as well as institutional and systemic factors: new public interventionism, new public governance and new forms of political governance, networks policy, and public policy. Regarding social science, this results in understanding and the necessity of describing innovativeness not only in reference to its technical, technological, or macroeconomic aspects, but primarily such non-technical aspects as social, political, and behavioural ones.

Consequently, these processes broaden the argumentation in favour of intervention of all types of stakeholders in the area of pro-innovation policy. Apart from the previous argument regarding the reliability of the market that provides the basis for the involvement 
of public authorities in these processes, an argument arises about the unreliability of the state and the necessity of switching from the logic of economy of scale to economy of scope (e.g., public authorities such as: ministries, agencies, and others non-majoritarian institutions). Translating this into the methodology of political science processes, we can say that the proinnovation policy is becoming an element of the democratic revisionism that is adjusting the democratic model to new challenges of globalisation and regionalisation. The main measures of this revisionism include effectiveness, efficiency, coherence, and the scope of participation (Bokajło \& Dziubka 2001, 21-27). As noted by M. Crozier and E. Friedberg, at present both formulation of the programme (agenda) of public policy, decision-making, and execution must be understood as a process of collective actions. Out of necessity and pragmatics, the official authority of political institutions to make decisions is being dispersed. Along with the democratic revisionism and diversification of public space, and especially political governance, connections arise across formal, vertical, and horizontal applications to divisions, authority, and competences, which affect the discussed changes and possible objections. Therefore, the previous majoritarian formula is enhanced and supplemented by the non-majoritarian formula of participation (Crozier \& Friedberg 1979]. As H. Izdebski put it, the public authorities are obliged to assume the role of moderating policy - public moderating (Izdebski 2007, 71; Löffler 2003, 166). The new challenges for political policies are presented in this way according to the idea of governance understood as a form of political system, the process of exercising power over the management of economic and social resources of the country, and the ability of the public authorities to formulate and execute policies. Thus, these are the elements of decentralised public governance. All of these arguments confirm the thesis about the differentiation and subjective integration in defining the pro-innovation policy (Sztopmka 2007, 508).

\section{Pro-innovation policy - a narrow and wide definition}

Knowing how the public policy develops, its functional perspective should also be defined. At first it can be characterised on the basis of general structural features which are specific to every public policy and defined as immature (relatively "young" and with no roots) and then as fragmented (objectively) and complex (subjectively) operations of public and private actors. The significance of the last two features can be further enhanced on the basis of studies by G. Majone and B. Jessop, who indicate the fact that this is a kind of policy space (Majone 2004, 239-240; Jessop 2002; Jessop 2006). This term is used to describe policy/ policies which are closely related to each other (holistic), and in effect it is impossible to usefully describe this policy, let along formulate analytical claims about it, without any account of the other elements of the set, as the pro-innovation policy is closely connected with other sectoral policies: science and research, industry, employment, environmental protection, military, healthcare, regional, education, and energy generation, etc. At this point we come across the policy of incomplete contracts, which means the necessity to make decisions jointly and the necessity to react to actions that are unpredictable and undesirable as well as impossible to design at the level of creating the policy agenda (Majone 2004, 54-56). Taking into account its diversified scope, how quickly external 
changes take place, and the necessary compatibility of external actions undertaken for the sake of effectiveness and rationality, the pro-innovation policy will always provide the dilemma of whether this is an effective or exercisable policy. The dilemma can be reduced by adequately defined taxonomy of restrictions - uncertainties in the scope of the designed strategies of action. For such a reduction to be visible and effective, as J. Hausner wants it to be, the space of such a policy must be sufficiently open, responsive, and communicated (Hausner 2008, 30-31). In this case, there must exist - as claimed by B. Jessop, J. Kooiman, and J. Hausner - a space beyond the system that is a multi-dimensional communication space between the functionally diversified entities and levels, including vertical (European, national, regional) and horizontal (research and development sector, sector of business environment institutions, sector of enterprises, sector of finances, public authorities at the national, regional, and local levels) levels (Hausner 2008, 397-402; Kooiman 2000; Jessop 2007). Due to such a space, these aspects of multi-dimensional communication get the possibility to change the identity of the system and policy, adjust, and mutually self-reference. However, in time, this must cause a problem of high-level coordination and thus meta-governance of a relatively decentralised context governance, which does not require hierarchy, but heterarchy (Wilke 2007, 127-138). Along with the development of space and the contractibility of public policy, the demand for rule intermediaries to assure proper coordination and effectiveness grows.

\section{Pro-innovation policy - internal aspects. The role of non-majoritarian institutions}

These rule intermediaries are described in the literature of the subject as non-majoritarian institutions or fragmented governance institutions. These are institutions operating in a public sphere demonstrating a quasi-governmental character (Black, Lodge, \& Theatcher 2005, 16-40; Theatcher 2002, 954-972). They take various legal forms: agencies, councils, and funds, etc. In the case of these institutions, the market and political logic should connect as closely as possible to serve the functions of social/public utility, on the one hand, and economic effectiveness, on the other hand. They are also an institutional condition of participation and legitimisation of a given public policy, and in a broader meaning, inclusion and co-responsibility for the common good. However, the condition of this inclusion and the quality of the common good, and in this case of public governance, within the pro-innovation policy, is the necessity of competent participation of the citizens, and therefore possession of axio-normative and intellectual qualifications (Dziubka 1998, 25-51). Sometimes this is also identified in the literature as a high quality of social capital, or in a broader meaning, human capital. Only after this condition is met can we avoid the tragedy of the commons (Hardin 1968, 1243-1248), that defines and implements the common good by collective rather than individual effectiveness and rationality. In pragmatics, the tragedy of the commons is described by such phenomena as rentseeking, bonding capital, iron shackles, and lobbing. Consequently, the quality of social capital and the dominant type of rationality determine the effectiveness of institutions of fragmented governance, which includes three elements (Szczerski 2005, 42-44): 
- structure of governance - assignment and structure of responsibility, administration tradition, national styles of regulations;

- method of governance - rules of governance in the sphere of financial and human resources, political culture, types of relations: confrontational or conciliatory, formal or informal rules;

- autonomy of decision-making - scope of independence, legal authorisation: contractual, result-oriented, long-term model.

However, in the practice of public activities, there exist frequent cases of shallow axionormative embedding, shallow institutionalisation, and an inefficient state. The reasons for this may be: too short a duration of the emergence of democratic mechanisms and democratic socialisation, strong interest groups, administration tradition and type of political culture, dominant discourses, and hierarchy of agendas for civilisational and social changes, etc. Thus, the referents indicate bad governance. This is the case when the initiation factor is not separated from the execution factor, and thus the policy starts to join the elements connected with gaining and maintaining power (politics) and with governance in the sphere of a specific set of public tasks (policy) (Izdebski 2007, 39). In effect, we have the strong involvement of the state in the processes of regulation, dominance of a principal-agent model in the place of a trust agency model in the development of non-majoritarian institutions, and the superficial character of public governance. In the literature, this phenomenon is described as the shadow of hierarchy, and again it requires the application of mechanisms connected more with imperative than interactive governance (Börzel 2009, 82-87).

\section{From pro-innovation policy to the National Innovation System (social and networking aspects)}

The pro-innovation policy understood as policy space, incomplete contracts, self-reference, and finally as meta-policy, consequently comes across the problem of structurisation and embedding. Based on the literature of the subject, and first of all on the achievements of the Aalborg school, drawing from the Schumpeterian workfare state as well as the Chicago school, one can try to describe the systemic and structural aspect of the pro-innovation policy within the frame of reference to national innovation systems. The National Innovation System (NIS) is most often defined as a complex of separate institutions which together or individually contribute to the development of a new economy, the so-called knowledge economy, creating at the same time an environment (basis) within which the government formulates and implements the innovation policy with non-majoritarian institutions. It can be said then that NIS is an institutional element of the innovation policy, implemented by a given state (Metcalfe 1995, 24-35).

The issue of NIS in Polish literature on political science, and in a broader meaning social science, is poorly described and researched, and it can be even said that it is negligible. There are also more than a dozen articles and papers published in periodicals or joint publications that take into account the perspective and methodology of the economic, technical, and legal sciences, whereas there are no such publications in the scope of political 
science. There are a few reports which were developed by the commission of the Polish Agency for Enterprise Development (PAED) and the Ministry of Science and Higher Education (MSHE), although they do not present this issue from the neo-institutional perspective of social science. In this context, one can propose a thesis that this is a new problem for political science that encompasses new forms of political representation, which are different than the discussed traditional aggregative formulas and presents new models of governance of the public sphere. The economic sciences or organisation and governance sciences mainly focus around the operationalisation of the model used for the first time in 1995 by H. Etzkowitz and L. Leydesdorff known as the triple helix model. It defines the dynamics of the connections between scientific research entities (research and development sector), industry (business), and administration (Etzkowitz \& Leydesdorff 2000, 109-123). This perspective is connected with the phenomenon of the postmodern political discourse in public governance, which in fact oversimplifies the analysis of complicated and multi-level public governance processes. This perspective corresponds to the popular opinion of J. Buchanan who claims that "disregard for political enforceability was considered a desirable feature; but the refusal to examine what is politically enforceable means incomplete science" (Buchanan 1997, 21). Taking the above into account, the structural aspects described here are an attempt to describe such an interdisciplinary matter as NISs with the use of the methodology of political science. Instead of discursive deliberations, I suggest using the nomothetic method, and its operationalisation by using the neo-institutional method.

Assuming this perspective, it is possible to use the methodology of grounded theory (one of the mid-range theories), according to which a given theory develops during systematically conducted field research from empirical data which relate directly to the observed part of social reality. Consequently, the theoretical proposals are not developed only by logical deduction on the basis of assumed axioms or assumptions. The theoretical constructs arise from the deductive analysis of phenomena and processes, but through empirical research, and in the case of grounded theory this is qualitative research which modifies and verifies a given reality. At this point it should be emphasised that quantitative research would not provide the answer to the fundamental questions regarding the system structure, variables affecting a given structure, the kind of dependencies and mechanisms that operate in it, the type of applied policy, and the ultimate structure of NISs; that is the answer to the question of why and how.

The axis of this type of research could emphasis the institutional, political, and legal issues regarding the innovation policy and system, specifically to determining the following variables:

\section{Structure of NIS}

- notion of NIS;

- system institutions'

- role and significance of non-majoritarian/structured institutions;

- role and significance of specific segments of NIS;

- possible specialisation of the system as a whole and its individual segments;

- the problem of coordination and concentration of actions and means 
- relations with other functional sub-systems.

2. Innovation policy

- Decision-making process - course, weak links;

- objectives and means of the innovation policy;

- participation and legitimisation;

- national and regional policy.

3. European context

- legal solutions - own or imitative, coercive vs. mimetic and functional isomorphism;

- financial possibilities - European trends and national perspective;

- role and tasks of the Presidency of the Council of the European Union.

This has made it possible to formulate conclusions regarding the policy, structure, system, and processes taking place in it, as well as the consequences for the social system.

The last stage of the research could be the development of a mental map for the neoinstitutional understanding of NIS and the innovation policy, which subsequently makes it possible to formulate a comprehensive analysis of cases described in the NIS literature in selected states. As a result of the application of the comparative method and assumption of the comparatistic model and gap aspects (also known as the method of concomitant variables and the method of difference), it is possible to identify similarities and differences between individual NISs as well as the conditions and paths of evolution of NIS. This last process is described in grounded theory as the constant comparative method and finishes the whole process of verification of theory and model with the pragmatics of actions taken in a given area. As K. Konecki and D. Silvermann put it, the methodology of grounded theory has modifiability and discursiveness aspects, which means that its construction is never complete (Konecki 2000; Silvermann 2009). This theory can be subject to permanent transformations caused by the provision of new data, new processes, and new issues, etc. Furthermore, this method only discusses the possibilities of accepting claims about a specific and separate area of social reality (NIS as a politically functional system), and as such demonstrates the features of a mid-range theory. Such a perspective of "openness" relates to a thesis which is popular in the methodology of the social and economic sciences by R. Lipsey, who wrote that during spontaneous transformations, a given theory can never be ultimately invalidated nor confirmed and that the only thing that can be counted on is the discovery on the basis of a finite amount of imperfect knowledge which of the alternative hypotheses is more probable (Lipsey 1989, 31-37). This in turn relates to the opinion of M. Blaug who making use of K. Popper's falsificationism claims that the methodology in the empirical sense is supposed to demonstrate not so much whether specific models are true or false, but whether they can be applied in a given situation, and thus whether they are a form of pragmatic falsificationism and the antithesis of naive or sophisticated falsificationism (Blaug 1995, 120-129).

On the other hand, in the foreign literature regarding NISs there is a great majority of publications regarding economics, including publications which belong to the previouslymentioned Aalborg school of innovation systems and policy (Lundvall 1992; Edqiust 1997; Nelson 1993), works by Ch. Freemann, who was the first to present this aspect of operations of states and economies, and works by P. Patel and K. Pavitt (Freemann 1995, 5-24; Patel 
\& Pavitt 1994, 77-95). Politological publications regarding the innovation system focus on the description of the development and governance of new public policies both at national and supra-national levels. This group includes works by B. Jessop, F. Scharpf, G. B. Peters, M. Olson, D. March, G. Majone, and G. Stoker. Their works demonstrate that greater participation of the public sector in the economy contributes to the growth of a knowledgebased economy. This thesis is confirmed by the fact that such Scandinavian countries as Sweden, Finland, and Denmark rank in economic competitiveness. Confirmation of this fact can be found in the Rank of Innovation Union Scoreboard (IUS), published every year by the European Commission. Since 2005, the Scandinavian countries have been located at the same top of this rank. In the last IUS, Sweden, Denmark, and Finland were classified as an innovation leaders' group. In addition to these three countries is Germany. The most innovative countries perform best in all dimensions: from research and innovation input, through business innovation activities, up to innovation output and economic effects, which reflects a balanced national research and innovation system. The Innovation leaders and Innovation followers, continuously have the smallest variance in their performance across all eight innovation dimensions. This means that in all dimensions, the performance of the Innovation leaders, Sweden, Denmark, and Finland, is not particularly different. The Innovation leaders are also mostly on top and clearly above the EU average (0.554), e.g., Sweden 0.750, Denmark 0.728, and Finland 0.684 (Innovation Union Scoreboard 2014, 6-8).

Publications regarding public policies do not include short-term analyses and do not analyse the emergence or operations of sub-functional political systems, and in the discussed case - NISs. As R.A. Dahl and B. Stinebrickner put it, the sub-functional system is a kind of structure with which a specific policy can be analysed. Furthermore, as noted by R.A. Dahl, societies which are modern (high level of GDP per capita, high level of consumption, education, urbanisation), dynamic (high rate of economic growth), and pluralistic (operation of independent groups, associations, organisations, low level of corruption), which Dahl calls New Dynamic Pluralistic Society (NDPS), demonstrate features favouring the diversification and specialisation of political systems and thus the development of a new sub-functional system (Dahl \& Stinebrickner 2007, 145-153).

The proposal for the development of R.A. Dahl's sub-functional systems and constitutive elements of the pro-innovation policy which are described above, correspond indirectly to the notion of N. Luhmann's autopoietic system. In Luhmann's opinion, the autopoietic (self-reference) system develops as a result of evolutionary differentiation of the system, and consequently political self-reference is a result of the social development of specific political sub-systems that constitute the structural element for the public policy being exercised. On the one hand, such a system and such a policy should not include any elements other than their own, so that everything a system is capable of doing is determined rather by endogenic factors, although in some circumstances (e.g., transformation and modernisation), the self-reference feature enables the system to be open to change. The self-reference system has three immanent features - differentiation (diversity), dynamics, and complexity (Luhmann 1994, 65-76; Luhmann 2007, 166-196). However, it should be noted that the purpose is a significant factor in the self-reference system, which is, as 
J. Goodin put it, a factor which should prevent its disorder and consequently its atrophy or morphostasis (Goodin 1996). Taking into account the purpose of the development of such a system, it should go through four stages of systemic change (Morawski 1998, 17-18):

1. Institutional development - deepening or extension of the principles which existed earlier;

2. De-institutionalisation of earlier structures;

3. Re-institutionalisation - change of rules, development of new ones;

4. Development of new institutions, which should distinguish the type of systemic changes from non-systemic changes.

The view of the morphogenetic cycle presented by W. Morawski as a system, which is neo-institutional, is complemented by the conditions of the development of the subfunctional systems presented by T. Parsons, which also feature four elements (Parsons 1977, 279-320):

1. Adaptation improvement - specialisation of the sub-system, adjustment of the system to the conditions;

2. Diversity - differentiation;

3. Inclusion into a new system;

4. Generalisation values - compatibility with other sub-systems and with the environment, which assures the performance of the integration function.

It is evident from the presented basic conditions, which are significant for the development of sub-functional systems, that the coexistence of institutional and legal conditions (de-institutionalisation, re-institutionalisation) with social and axiological conditions (inclusion, communication, valuation) must emerge. Only the convergence of these two processes can cause the successful development of a new structural dimension, and consequently provide the modernisation and civilisational effect. Otherwise, only individual and isolated effects are noticed, which do not cause added value for the system.

Placing the literature deliberations on the neo-institutional and structuralistic approaches presented above, which are used to describe the functional sub-systems, one can try to classify the scientific approach to NISs.

From the point of view of processes, six paradigms of understanding NISs (Edqiust 2004) can be distinguished:

- historic perspective of evolution - postmodern paradigm;

- holistic and interdisciplinary approach - systemic paradigm;

- focus on the role and significance of institutions - neo-institutional paradigm;

- result approach, supply-demand approach to innovations - functional paradigm;

- focus on interdependence and nonlinearity, processes of mutual learning - cooperation paradigm;

- centralisation versus regionalisation in the approach to innovation processes - space and territory (decentralistic and pro-competition or centralistic and flattening paradigm).

Relying on the publications of the Aalborg school and applying them to the model of autopoietic systems by N. Luhmann and G. Teubner, one can demonstrate how the sub- functional systems can become relevant (Teubner 1993; Luhmann 1994; Luhmann 
2007). I have seen this relevance through the prism of the degree of structuralisation (transparency) of institutions of the system, the scope of legitimisation of operations, including holistic solutions, connections with pro-innovation policy objectives and tools, and the method and development of non-majoritarian institutions.

\section{Pro-innovation policy - aspects of external implications using the example of the Europeanisation process}

The observation presented above demonstrates that the determinism of the national conditions also has a key significance for the development and creation of the EU's proinnovation policy, while on the other hand, it affects the effectiveness and efficiency of the adaptation of the solutions and means from a European to a national level, and further to a regional one. I assume then that, firstly, it is not possible at the present stage of development of the EU to implement the Lisbon Strategy or the Europe 2020 Strategy in a specific one best way, and consequently, secondly, the presence of the state in the scope of creating competitiveness as well as the EU and nation states is necessary. This perspective also provides the possibility of searching for the answer to the question to what degree a given entity (international organisation, industry, state, enterprise) is able to join and anticipate the changes taking place as a result of both processes of globalisation and Europeanisation. This in turn shall allow for formulating a forecast of the type of isomorphic institutional change in the context of modernisation processes. The type of isomorphic change allows for a search for empirical and normative dependence, beginning from coercive isomorphism - as a behaviour legitimising specific actions, that is passive submission to sub-national discourses through the mimetic isomorphism understood as a reaction to uncertainty and its prevention. This is possibly a reasonable adjustment to the context, which generates objective benefits from it to the normative isomorphism regarding the professionalisation of actions that is the cognitive and anticipatory dimension of exercising policy. In effect of this analysis, we can distinguish entities and intuitive levels, both primary and secondary, imitative within the pro-innovation policy (Di Maggio \& Powell 1983, 147-160).

\section{Pro-innovation policy - from quantitative to qualitative analysis}

The pro-innovation policy and the functional sub-systems which are developed for specific governance of that aspect of public and private actions are one of the most complex and consequently not always efficiently identifiable structural actions. The contexts of space: European - national - regional, as well as processes: sectoral - public - private - behavioural, create a very complicated network of connections, implications, and models of behaviour and actions. As a result of this complexity, the description of the pro-innovation policy only and mainly with quantitative variables, trivialises the scope and generates false alternatives. One of them was the opinion that was present in the world literature in the 1980s and early 1990s, and still in Poland at the beginning of the 21st century, that there is a close and linear relation between the growth of expenditure on research and development, the number of patents, the number of researchers, and the 
growth of GDP. If this thesis were actually confirmed, then many countries would redirect the streams of money to that area of public activities. Today, it is well-known that this is a multi-level process and quantitative factors can only be a basis for further analyses.

This is the exactly how OECD formulates its recommendations regarding the research of the innovation processes in the macro-, micro-, and mezzo-structural scale. In its third edition, which was published in 2008, The Oslo Manual. Proposed Guidelines for Collecting and Interpreting Technological Innovation Data presents the imperfections of the quantitative methodology in several places. First, it is noted that relatively little knowledge of innovations which are not technological and made in the public sector exists. As the Manual's author put it:

There is still a lot do be done in respect of studies on innovations and the development of a system of measurement used in gathering and interpreting data on innovations in the public sector. Work in this area could be the basis of a separate manual (Oslo Manual 2008, 18).

Consequently - second - an obvious observation can be made which affected my motivation to develop a formula for qualitative research and look at policy and the innovation system from a different, qualitative point of view. As noted by OECD experts:

It is essential to feed the debate on policy issues with information and analysis of many aspects of innovation. Ideally, a comprehensive information system should be construed that covers all types of factors within the innovation policy terrain. This would place governments in a strong position to deal appropriately with any particular policy issues that might arise. In practice, only parts of such a system can be covered by indicators, while other parts call for qualitative information. (...) (The qualitative) indicators will only occasionally relate to a single factor or issue, and more often than not will relate to a range of matters and partially to each. Any broad information or monitoring system will also need to be supplemented with case studies where specific in-depth analysis is required (Oslo Manual 2008, 42).

All issues regarding the pro-innovation policy are unlikely to be grasped because of its complexity (space policy), permanent development (policy of incomplete contracts), and the multi-level nature of processes. This is, however, why this area needs even deeper research in order to mobilise the right resources, build real development scenarios as well as successfully implement and at the same time shape emerging development processes.

Otherwise, the scenario of constant catching up, adaptability, and running out of simple resources as well as comparative advantages will become real. It is, however, important for all changes to be placed (embedded) within a context to evolutionarily reconfigure reality, making use of the processes of cooperation, learning, and diffusion.

\section{References}

Black, J., Lodge, M. \& Theatcher, M. (2005). Regulatory Innovation. A Comparative Analysis. Northampton: E. Elgar.

Blaug, M. (1995). Metodologia ekonomii. Warszawa: PWN.

Bokajło, W. \& Dziubka K. (ed.) (2001). Społeczeństwo obywatelskie. Wrocław: Wydawnictwo Uniwersytetu Wrocławskiego. 
Börzel, T. (2009). Nowe metody zarządzania a rozszerzenie Unii Europejskiej - paradoks podwójnej słabości. In: Kolarska-Bobińska L. ed. Nowe metodyzarządzania w państwach Unii Europejskiej. Warszawa: Instytut Spraw Publicznych.

Buchanan, J. (1997). Finanse publiczne w warunkach demokracji. Warszawa: PWN.

Crozier, M. \& Friedberg, E. (1979). Macht und Organization. Die Zwänge Kollektiven Handeln. Königstein: Atheneum Verlag.

Dahl, R. \& Stinebrickner, B. (2007). Współczesna analiza polityczna. Warszawa: Wydawnictwo Scholar.

Di Maggio, P. \& Powell, W. (1983). The Iron Cage Revisited: Institutional Isomorphism and Collective Rationality in Organizational Fields. American Sociological Review. Vol. 48, No.2.

Dziubka, K. (1998). Inkluzja polityczna jako wartość demokratyczna. In: Jabłoński A., Sobkowiak L. eds. Studia z teorii polityki, Vol. 3 Wrocław: Wydawnictwo Uniwersytetu Wrocławskiego.

Edquist, C. (ed.) (1997). Systems of Innovation: Technology Institutions and Organisations. London: Pinter.

Edquist, C. (2004). Systems of Innovation - A Critical Review of the State of the Art. In: Fagerberg J., Mowery D., Nelson R. Handbook of Innovation. Oxford: Oxford University Press.

Etzkowitz, H. \& Leydesdorff, L. (2000). 'The dynamics of innovation: from National Systems and 'Mode 2' to a Triple Helix of university-industry-government relations'. Research Policy. Vol. 29, No. 2.

Freeman, Ch. (1995). 'The 'National Systems of Innovation' in Historical Perspective', Cambridge Journal of Economics, Vol. 19, No. 1.

Goodin, R. (ed.) (1996). The Theory of Institutional Design. Cambridge: Cambridge University Press.

Hardin, G. (1968). 'The Tragedy of the Commons'. Science 13, Vol. 162/3859.

Hausner, J. (2008). Zarządzanie publiczne. Warszawa: Wydawnictwo Scholar.

Innovation Union Scoreboard 2014, European Commission, Brussels.

Izbebski, H. (2007). Fundamenty współczesnych państw. Warszawa: Wydawnictwo Prawnicze Lexis Nexis.

Jessop, B. (2002). The Future of the Capitalist State. Cambridge: Cambridge Polity.

Jessop, B. (2007). Promowanie dobrego rządzenia i ukrywanie jego słabości. In: Zarządzanie publiczne. nr 2 (2). Warszawa: Wydawnictwo Scholar.

Jessop, B. \& Sum, N.-L. (2006). Beyond the Regulation Approach. Putting Capitalist State in its Place. Northampton: E. Elgar.

Konecki, K. (2000). Studia z metodologii badań jakościowych. Teoria ugruntowana. Warszawa: PWN.

Kooiman, J. (2000). Societal governance. Levels, modes and orders of social-political interaction. In: Debating Governance: Authority Steering and Democracy. Oxford: Oxford University Press.

Lipsey, R. (1989). An Introduction to Positive Economics. London: Weidenfeld \& Nicolson. 
Löffler, E. (2003). Governance and Government. Networking with External Stakeholders. In: Bovaird, T. \& Löffler, E. eds. Public Management and Governance. London-New York.

Luhmann, N. (1994). Teoria polityczna państwa bezpieczeństwa socjalnego. Warszawa: PWN.

Luhmann, N. (2007). Systemy społeczne. Zarys ogólnej teorii. Warszawa: Zakład Wydawniczy NOMOS.

Lundvall, B-Å. (ed.) (1992). National Systems of Innovation: Towards a Theory of Innovation and Interactive Learning. London: Pinter.

Majone, G. (2004). Dowody, argumenty, perswazja w procesie politycznym. Warszawa: Wydawnictwo Scholar.

Metcalfe, S. (1995). The Economic Foundations of Technology Policy: Equilibrium and Evolutionary Perspectives. In: Stoneman P. ed. Handbook of the Economics of Innovation and Technical Change. London.

Morawski, W. (1998). Zmiana instytucjonalna. Społeczeństwo - gospodarka - polityka. Warszawa: PWN.

Nelson, R. (ed.) (1993). National Innovation Systems: a Comparative Analysis. Oxford: Oxford University Press.

Oslo Manual 2008, Guidelines for Collecting and Interpreting Innovation Data, OECD, Paris.

Parsons, T. (1977). Social Systems and the Evolution of Action Systems. New York.

Patel, P. \& Pavitt, K. (1994). 'National Innovation Systems: Why they are Important, and how they might be Measured and Compared. Economics of Innovation and New Technology. Vol. 3.

Silvermann, D. (2009). Interpretacja danych jakościowych. Metody analizy rozmowy, tekstu $i$ interakcji. Warszawa: PWN.

Szczerski, K. (2005). Administracja publiczna $w$ modelu zarządzania wielopasmowego. Natolin: Centrum Europejskie.

Sztompka, P. (2007). Socjologia. Analiza społeczeństwa. Kraków: Wydawnictwo Znak.

Teubner, G. (1993). Law as an Autopoietic System. Oxford: Oxford University Press.

Theatcher, M. (2002). 'Regulation after Delegation: independent regulatory agencies in Europe'. Journal of European Public Policy. Vol. 9, No. 6.

Wilke, H. (2007). Tragedia państwa. Prolegomena do teorii państwa i policentrycznego społeczeństwa. In: Zarządzanie publiczne Vol. 1, No. 1. Warszawa: Wydawnictwo Scholar. 